\title{
The type 4 pilin of Moraxella nonliquefaciens exhibits unique similarities with the pilins of Neisseria gonorrhoeae and Dichelobacter (Bacteroides) nodosus
}

\author{
Tone Tønjum, ${ }^{1 *}$ Carl F. Marrs, ${ }^{2}$ Frank Rozsa ${ }^{2}$ and KJell Bøvre ${ }^{1}$ \\ ${ }^{1}$ Kaptein W. Wilhelmsen og Frues Bakteriologiske Institutt, University of Oslo, Rikshospitalet, N-0027 Oslo 1, Norway \\ ${ }^{2}$ Department of Epidemiology, University of Michigan, Ann Arbor, Michigan 48109, USA
}

(Received 11 February 1991; revised 3 June 1991; accepted 27 June 1991)

\begin{abstract}
Moraxella nonliquefaciens is a bacterium which is part of the normal flora of the human upper respiratory tract and is an occasional cause of disease. Using a previously cloned type 4 pilin gene $(t f p Q)$ from Moraxella bovis as a hybridization probe, we have cloned an 826 bp Sau3AI fragment which contains an M. nonliquefaciens type 4 pilin gene $(t f p A)$ from strain NCTC 7784. The pilin gene is expressed in Escherichia coli. We have examined NCTC 7784 and nine other $M$. nonliquefaciens strains by genomic Southern hybridization using $t f p A$ as a probe, and they all appeared to have more than one pilin gene. While the predicted amino acid sequence of the $M$. nonliquefaciens $t f p A$ pilin has conserved regions as compared to pilins of $M$. bovis and $M$. lacunata, it also shows similarities to both the type 4 pilin of Neisseria gonorrhoeae and the type 4 pilin of Dichelobacter nodosus (formerly Bacteroides nodosus).
\end{abstract}

\section{Introduction}

Moraxella nonliquefaciens is part of the normal bacterial flora in the human upper respiratory tract, particularly the nasal cavity (Bøvre, 1984; Henriksen, 1973). It has also been isolated from blood, sometimes associated with septicaemic disease, from cerebrospinal fluid, and from eye, lower respiratory tract, and other local infections (Brorson et al., 1983; Bøvre, 1984; Ebright et al., 1982; Graham et al., 1990; Lobue et al., 1985; Rosett et al., 1976; Sharma, 1974). Generally, the species is considered to be of low pathogenicity, depending on reduced host resistance for invasion and clinical manifestations. Together with Moraxella bovis and Moraxella lacunata, $M$. nonliquefaciens makes up the very closely related 'classical moraxellae' (Bøvre, 1984). As studied in $M$. bovis, in particular, $M$. nonliquefaciens has a wide variety of phenotypes associated with piliation (fimbriation), including spreading and/or corroding growth on agar (Bøvre et al., 1970; Bøvre \& Frøholm, 1972a, b), twitching motility (Henrichsen et al., 1972), haemagglutination (Schoolnik et al., 1982), surface pellicle formation in static broth (Bøvre et al., 1970; Bøvre \& Frøholm,

The nucleotide sequence data reported in this paper have been submitted to GenBank and have been assigned the accession number M 59707. 1972a) and competence for genetic transformation (Bøvre \& Frøholm, 1972b). M. nonliquefaciens also undergoes phase variation of colony morphology (Bøvre \& Frøholm, 1972a), switching between spreadingcorroding (SC) growth and smooth, non-corroding (N) colonies. Piliation is found in SC, but generally not in $\mathrm{N}$ colonies (Bøvre \& Frøholm, 1972a, b). Spontaneous change from $\mathrm{SC}$ to $\mathrm{N}$ may be observed easily in surface cultures on solid medium. Spontaneous $\mathrm{N}$ to SC variation is generally less easy to observe, sometimes only detectable through the occasional formation of a pellicle on the surface of static broth culture. Thus, it seems that $M$. nonliquefaciens undergoes the phase variation associated with type 4 pili that is seen in other species (Bergstrøm et al., 1986).

Members of the type 4 (MePhe) class of bacterial pili are found on a variety of Gram-negative bacteria (Dalrymple \& Mattick, 1987), including M. bovis (Marrs et al., 1985), M. lacunata (Marrs et al., 1990), Neisseria gonorrhoeae (Hermodson et al., 1978), Neisseria meningitidis (Hermodson et al., 1978), Dichelobacter nodosus [formerly Bacteroides nodosus (Dewhirst et al., 1990)] (Elleman \& Hoyne, 1984), Pseudomonas aeruginosa (Sastry et al., 1985), and Vibrio cholerae (Taylor et al., 1987). The main structural subunits of these pili (pilins) share extensive amino-terminal amino acid sequence homology, and all except $V$. cholerae contain the modified amino acid $N$-methylphenylalanine as the first 
residue of the mature protein (McKern et al., 1983; Taylor et al., 1987). The amino acid sequence of the amino-terminal end of the pili in $M$. nonliquefaciens NCTC 7784 was determined by Frøholm \& Sletten (1977). Comparison of the amino acid sequence of type 4 pilin from different species to the original $M$. nonliquefaciens sequence demonstrated that it also belonged to the type 4 pilins (Dalrymple \& Mattick, 1987).

Differences exist in the copy numbers of pilin genes among bacterial species containing type 4 pili. $P$. aeruginosa strains have only a single copy of the pilin gene in each genome (Sastry et al., 1985). Most serotypes of $D$. nodosus only have a single gene, but some have two (Mattick, 1989). N. gonorrhoeae strains contain multiple pilin gene loci, and transitions between $\mathrm{P}^{+}$and $\mathrm{P}^{-}$and between different $\mathbf{P}^{+}$pilin types are often accompanied by chromosomal DNA rearrangements (Bergstrøm et al., 1986; Swanson \& Koomey, 1989; for a review, see Swanson et al., 1987). M. bovis and M. lacunata strains each express one or the other of two different pilin genes, and can switch between them via a $2.1 \mathrm{~kb}$ DNA inversion event (Fulks et al., 1990; Marrs et al., 1988, 1990).

In this report, we describe the cloning, sequencing and expression of an $M$. nonliquefaciens pilin gene, $t f p A$. Hybridization analysis of a panel of $10 \mathrm{M}$. nonliquefaciens strains was performed. Comparison of the deduced amino acid sequence to other reported type 4 pilin protein sequences revealed new information on differences from and features shared with other species.

\section{Methods}

Bacterial strains, plasmids, and media. Strains of $M$. nonliquefaciens included in the study were NCTC 7784 (ATCC 17953), 4663/62 (ATCC 19975, type strain), ATCC 19968 (836/61), 178/62, 4378/62, 13385/62 (ATCC 19969), 3067/66, 3179/66, 3832/60 (ATCC 19966), and B2000/88. All (except NCTC 7784) had been isolated in our laboratories. B2000/88 originated from the blood of a leukaemic child with septicaemia. The strains were identified by genetic transformation (Bøvre, 1964; Bøvre \& Frøholm, 1972; T. Tønjum \& K. Bøvre, unpublished). $M$. nonliquefaciens as well as $M$. bovis ATCC 10900 (type strain) and $M$. lacunata ATCC 17967 (type strain) were grown on $5 \%$ (v/v) human blood agar (Difco; Bøvre \& Frøholm, 1972). Escherichia coli PLK-F' $\left[\right.$ recA, mcrAB, hsdR, hsd $M^{+}, \mathrm{F}^{\prime}\left(\operatorname{lacZ\Delta 15}\right.$ lacl $\left.\left.^{9}\right)\right]$ (Stratagene) was used as a host for cloning, as it has the $\operatorname{mcr} A B$ negative background suitable for cloning methylated DNA (West \& Clark, 1989). E. coli containing drug-resistant plasmids were grown on LB agar containing either $25 \mu \mathrm{g}$ kanamycin (Sigma) $\mathrm{ml}^{-1}$ (LBkan) or $100 \mu \mathrm{g}$ carbenicillin (Beecham Pharmaceuticals) $\mathrm{ml}^{-1}$ (LBcb), as appropriate. The low copy number $\mathrm{Kan}^{\mathrm{R}}$ vector $\mathrm{pLG} 339$ was obtained from Dr Bob Bender, University of Michigan, Ann Arbor, Michigan, USA (Stoker et al., 1982). The plasmid pMxB12, which contains the $M$. bovis tf $Q$ pilin gene, has been described previously (Fulks et al., 1990; Marrs et al., 1985).

DNA isolation and manipulation. Total DNA was prepared by the method of Hull et al. (1981). Plasmid DNA isolation was performed according to the method of Birnboim \& Doly (1979). Restriction endonucleases were purchased from Bethesda Research Laboratories, Boehringer Mannheim or Promega. Restriction endonuclease digestions and agarose gel electrophoresis were performed as previously described (Marrs et al., 1985). DNA transfer from agarose gels to nylon membrane (Hybond- $\mathrm{N}$, Amersham) was done by a modification of the method of Southern (1975), using the Vacu-Gene System (PharmaciaLKB). Hybridizations were performed at stringent conditions as previously described (Marrs et al., 1985; Tønjum et al., 1989). The tfpQ pilin probe from plasmid $\mathrm{pMxB12}$ was labelled with $\left[\alpha-{ }^{32} \mathrm{P}\right] \mathrm{dCTP}$ (Amersham) by use of a random oligo-priming kit (Boehringer Mannheim).

Inserts of size-fractionated Sau3AI fragments of total $M$. nonliquefaciens NCTC 7784 DNA were obtained by electro-elution from $1 \%(w / v)$ agarose (SeaKem, FMC Bioproducts). Inserts were ligated into the Bam HI-cleaved pLG339, transformed into competent E. coli PLK-F' cells and selected on LBkan plates. $\mathrm{Kan}^{\mathrm{r}}$ transformants were screened for hybridization to the $t f p Q$ probe by a colony blot method (Sambrook et al., 1989). The insert of one hybridization positive clone (pMxN7) was then subcloned into the vector pGEM7 (Promega) at the BamHI site. One of the resulting plasmids (pMxN11) was chosen for detailed analysis.

The DNA sequence of the insert region of $\mathrm{pM} \times \mathrm{N} 11$ was determined using the dideoxy-chain termination method of Sanger et al. (1977). The primers T7 (5'-TAATACGACTCACTATA- $\left.3^{\prime}\right)$ and SP6 (5'TAAATCCACTGTGATAT- $3^{\prime}$ ) are in the pGEM7 vector flanking the insert. The primers $\mathrm{Mnl}$ (5'-CAACCGTGTCTGTTACGTTGTC-3'), Mn3 (5'-GATACAGCTGCAGATGGCG-3'), and Mn4 (5'-CTAGCACTAGCTTACCTGC-3') were also used for sequencing and their positions are shown in Fig. 1. Sequence analysis was performed using computer software from DNASTAR Inc., Madison, Wisconsin, USA.

Western blotting (immunoblotting). Proteins of whole-cell extracts of bacteria were boiled in loading buffer, separated according to molecular mass by SDS-PAGE and transferred to a nitrocellulose filter (Immobilon-P, Millipore) (Towbin et al., 1979). Crudely purified pili and rabbit antiserum 130D raised against purified pili of $\boldsymbol{M}$. nonliquefaciens NCTC 7784 was kindly provided by Dr L. O. Frøholm, Folkehelsa, Oslo, Norway. The antiserum was diluted 1:1000 for reaction with the filters.

\section{Results}

\section{Cloning of the $M$. nonliquefaciens pilin gene}

Since $M$. bovis and $M$. nonliquefaciens are closely related, we decided to use the previously cloned $M$. bovis $t f p Q$ pilin gene as a hybridization probe to detect the equivalent $M$. nonliquefaciens pilin gene. To determine hybridization conditions and optimal restriction enzymes for cloning the $M$. nonliquefaciens pilin gene, we performed genomic Southern hybridization analysis on restriction endonuclease digested $M$. nonliquefaciens total DNA using the $t f p Q$ pilin gene as a probe (Fig. 2). Based on these results, we decided to clone the approximately 800 bp hybridizing Sau3AI fragment into the high copy number plasmid vector pGEM7 in E. coli. After several unsuccessful attempts to do this directly, we first cloned the fragment into the low copy number plasmid vector 

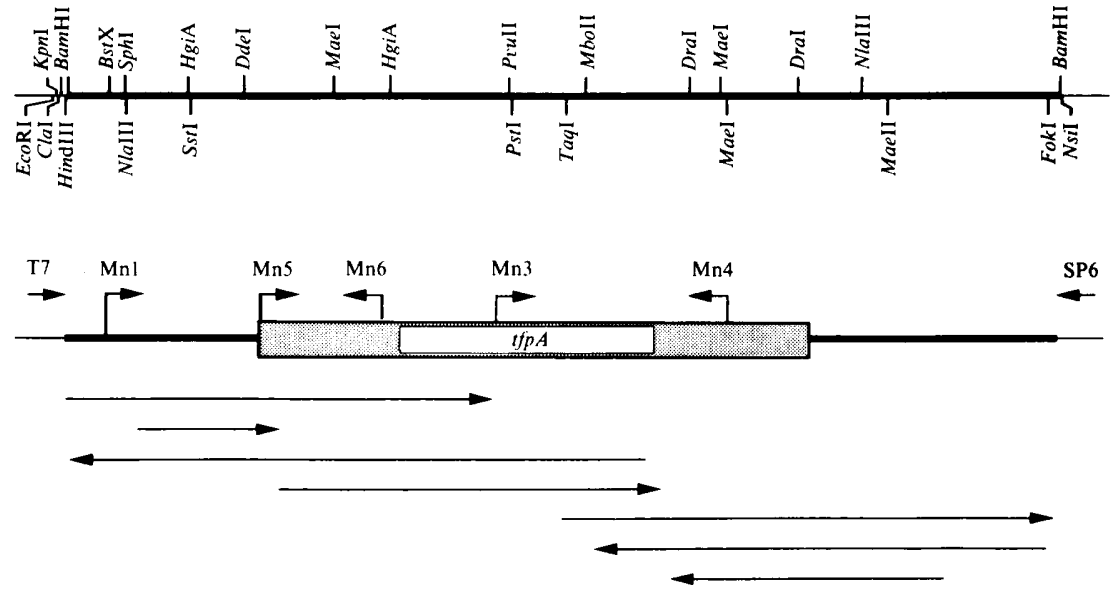

Fig. 1. Restriction map of the insert region of pMxN11, encoding the $M$. nonliquefaciens NCTC 7784 tfpA gene, and strategy for determining the sequence of the insert region. The insert region is represented by the bold line between the BamHI sites. A few sites in the linker regions of the pGEM7 vector portions of $\mathrm{pMxN} 11$ are also listed. The positions of the oligonucleotide primers used to determine the DNA sequence (T7, Mnl, Mn3, Mn4 and SP6) and for PCR and oligohybridization studies (Mn5 and Mn6) are shown, as is the relative position of the gene within the insert. The arrows beneath the map show the direction of sequencing and the length of the sequence determined by using the listed oligonucleotide primers.
pLG339 in the $m c r A^{-} B^{-} E$. coli host strain PLK-F'. The insert region of the resultant recombinant plasmid (pMxN7) was then subcloned into pGEM7 producing the plasmid $\mathrm{pMxN} 11$. A restriction map of $\mathrm{pMxN} 11$ is presented in Fig. 1.

\section{Sequencing the $M$. nonliquefaciens pilin gene clone}

The strategy used for sequencing the BamHI insert portion of $\mathrm{pMxN} 11$ is shown in Fig. 1. The sequence of the entire insert was determined in both orientations using five oligonucleotide primers whose positions are shown in Figs 1 and 3. The nucleotide sequence of $826 \mathrm{bp}$ between, but not including, the Bam HI sites is presented in Fig. 3, together with the predicted amino acid sequence of the pilin. We have named this pilin gene tfpA. The sequence AGGAG present on the 5' side of the starting ATG is homologous to known ribosome-binding sites in prokaryotes (Gold et al., 1981) and is identical to the ribosome-binding sequence of both an $N$. gonorrhoeae pilin gene (Meyer et al., 1984) and the $M$. bovis tfp $Q$ pilin gene (Marrs et al., 1985).

\section{Southern blot analysis using a tfpA probe}

When stringent hybridization conditions were used, it became clear that genomic DNAs of the $M$. bovis and $M$. lacunata type strains hybridized relatively poorly to the $M$. nonliquefaciens $t f p A$ probe, as compared to hybridization of $M$. nonliquefaciens NCTC 7784 genomic DNA to both $t f p A$ and the $M$. bovis tfp $Q$ probe (Fig. 2).

As described in the Introduction, the number of pilin genes or partial pilin genes varies greatly among the bacteria that express type 4 pili. Therefore, we wanted to determine the number and organization of the pilin gene(s) of $M$. nonliquefaciens. The BamHI insert fragment of pMxNll was used as a probe in stringent genomic Southern hybridizations to both the parent strain NCTC 7784 and nine additional $M$. nonliquefaciens strains (Fig. 4). This analysis reveals several bands of strong and weaker hybridization with all of them. The parent strain deviates by having much smaller sized bands than the other strains.

\section{Western blot analysis}

As demonstrated in Fig. 5, the 130D antiserum reacted with a protein band from $M$. nonliquefaciens at $15 \mathrm{kDa}$. This band is equal in size to the band appearing with purified pili. A similar band, only migrating slightly more slowly, was recognized when cell extracts of $E$. coli containing $\mathrm{pMxN} 11$ were reacted with the antiserum. The antiserum also reacted with higher molecular mass proteins that could be either pilin multimers or crossreacting proteins (data not shown).

\section{Amino acid analysis}

The inferred amino acid sequence of the $M$. nonliquefaciens pilin protein based on the nucleotide sequence (Fig. 3) shows a six amino acid leader sequence preceding the phenylalanine which starts the mature protein. This leader is identical to the leader sequences of $M$. bovis and M. lacunata pilins (Fig. 6). The predicted amino acid sequence matches almost perfectly with the aminoterminal amino acid sequence reported by Frøholm \& 


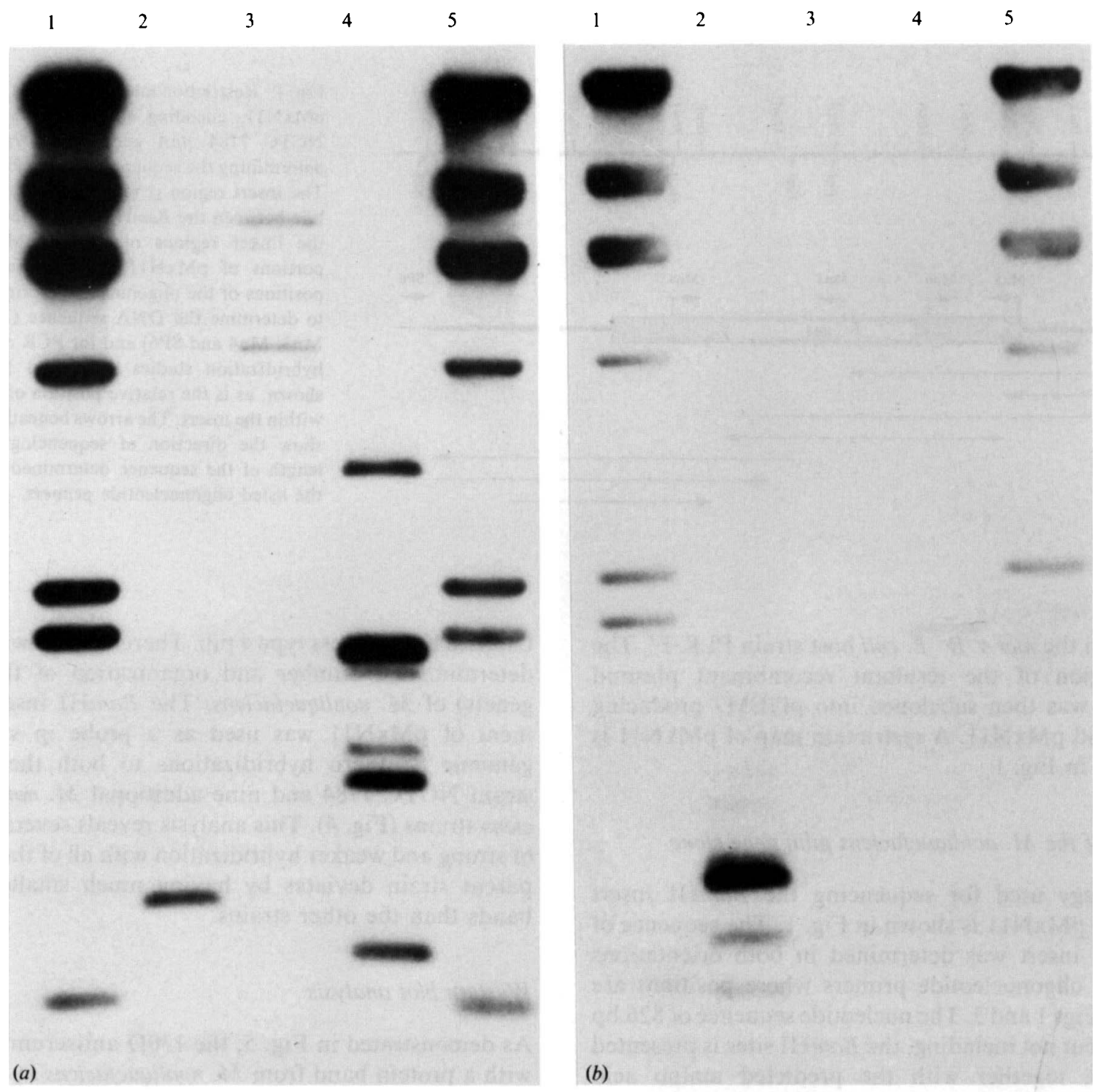

Fig. 2. Genomic Southern hybridization of $M$. nonliquefaciens, $M$. lacunata and $M$. bovis DNAs using inserts of $(a)$ the $M$. bovis $\mathrm{pMxB} 12$ $(t f p Q)$ and $(b)$ the $M$. nonliquefaciens $\mathrm{pMxN} 11(t f p A)$ as probes at a sodium salt concentration of $0 \cdot 1 \mathrm{M}$ and a temperature of $65^{\circ} \mathrm{C}$. Lanes: 1 and 5, $\lambda /$ HindIII marker DNA visualized with a small amount of labelled $\lambda$ DNA; $2, M$. nonliquefaciens NCTC 7784/Sau3AI; 3, M. lacunata ATCC 17967/Sau3AI; 4, M. bovis ATCC 10900/Sau3AI.

Sletten (1977). The only difference is at position 46 of the mature pilin where they had tentatively identified the residue as Gly, whilst in our predicted sequence this would be a Ser residue.

\section{Discussion}

Dalrymple \& Mattick (1987) classified the $M$. nonliquefaciens NCTC 7784 pilin as a type 4 pilin with strong amino acid sequence conservation compared at the amino terminus to all other type 4 pilins, including that of $M$. bovis. The data presented here describe the successful use of an $M$. bovis tfp $Q$ pilin gene probe to isolate a pilin gene from $M$. nonliquefaciens, tfp $A$. When stringent hybridization conditions were used, it became clear that the $t f p A$ pilin gene probe hybridized relatively poorly to total genomic DNA of $M$. bovis as well as $M$. lacunata. This was surprising, considering that the $M$. bovis tf $p Q$ pilin gene probe hybridized clearly to genomic DNA of $M$. nonliquefaciens (Fig. $2 a$ ) and that distinction between these very closely related species by hybridization of total DNA under the same conditions is difficult (Tønjum et al., 1989). The $M$. bovis pilin gene probe 
$\mathrm{MnI} \longrightarrow$

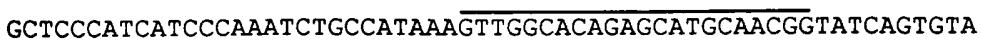
AGTTAGCAAGATTAGCAGTACAGTCATCAGACTGCTTTGTTAATCGTTGCAAATAACATC tfpA $\longrightarrow$ MnS TAATAACTGGGCAATTCTGCCCACCTAACTAAGGAGTTCATTA TGAACGCTCAAAAAGGT MetAsnAlaGlnLysGly

TTTACCCTAATTGAATTGATGATTGTTATCGCCATTATTGGTATCCTAGCTGCCATCGCA PheThrLeuI legluLeuMetI leVaIIleAlaIleIleGly I leLeuAlaAlaI leAla Th6

TTGCCTGCGTATCAGGACTATATCGCCCGTGCACAGGTATCAGAAGCCTTTACTTTGGCT LeuP rOAI TY GINASPTYI leAlaArgAlaGInVaISerGluAlaPheThrLeuAla

GATGGACTAAAGACCAGCATCAGCACCAACCGTCAAAATGGGAGATGTTTTGCTGATGGT AspGIyLeuLysThrSerIleSerThrAsnArgGInAsnGIYArgCysPheAlaAspGIY $\mathrm{Mn} 3 \longrightarrow$

AAAGATACAGCTGCAGATGGCGTAGATATAATAACAGGTAAGTATGGTAAAGCCACTATT IysAspThrAlaAlaAspGIyValAspIleIleThrGIyLysTyrGlyLysAlaThrIle

CTCGAAGAAAACCCTAATACTGCTGATGGTTTAATTTGTGGTATTTATTATGAATTTAAC

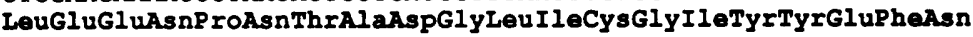

ACGACTGGCGTATCTGATAAGCTGATTGGAAAAACGATTGCTTTAAAAGCAGATGAGAAA 540 ThrThrGlyValSerAspLysLeuIleGlyLysThrIleAlaLeuLysAlaAspGluLys

$\longrightarrow \mathrm{Mn} 4$

GCAGGTAAGCTAGTGCTAGAAACTGTTAATTCTAAAACTACAAATGTTGAGAATAAATAT AlaGlyLysLeuVaILeuGluThrVa IAsnSerLysThrThrAsnValGluAenLyeTyr

CTCCCAAGTGCTTTTAAAAAGCCTTAATAAAAAACAACAGTCTCAAAAAAAAACAAGCTC LeuP roSerAlaPheLysLysP ro

TCATGAGAACTTGTTTTTTTGACATTACGTTGTATGGAAGTTGATTATTATCTAAAAGC

ACTTGGGAGATATTTACTTGGAACATTTGTACTTTTAGATTTAACAGTTTCCAATTTTAA
780

Fig. 3. Nucleotide sequence and translation of the pMxN11 insert containing the $M$. nonliquefaciens NCTC 7784 tfpA gene. The predicted amino acid sequence of the open reading frame containing the coding sequence of pilin is shown; the amino acids present in the mature protein are in bold type. The AGGAG sequence (underlined) upstream of the starting Met is the putative ribosome-binding site. The positions to which the internal sequence primers bound are represented by the lines above the sequence with the primer name above that. Primer Mnl (sequence listed in Methods) was constructed based on the sequence of the equivalent regions of sequence in $M$. bovis and $M$. lacunata, and is not the perfect complement of the sequence shown in this figure.

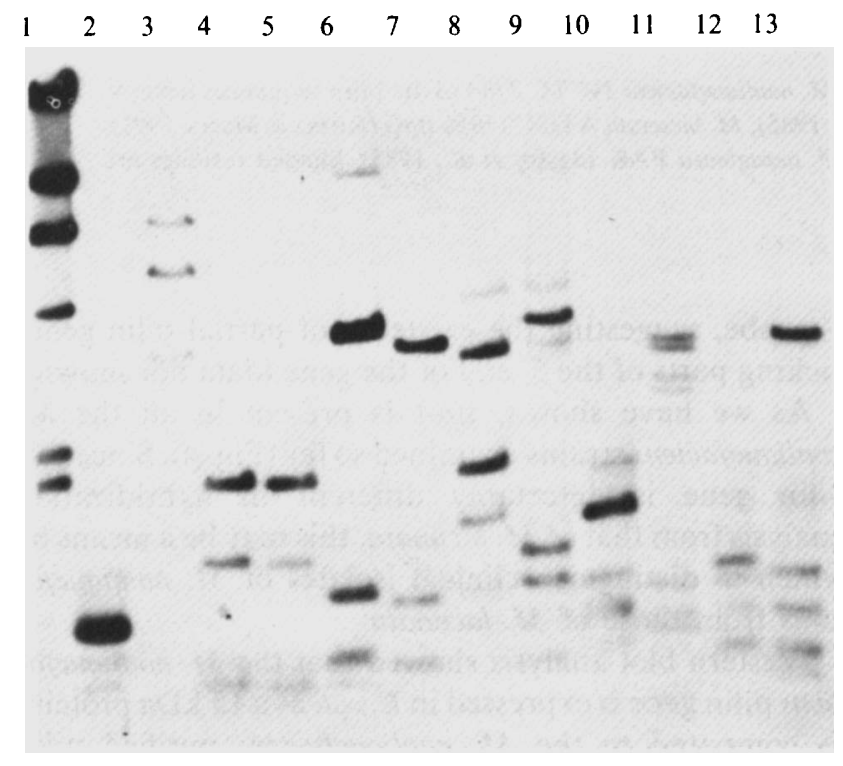

Fig. 4. Genomic Southern hybridization of a panel of $M$. nonliquefaciens strains using the $M$. nonliquefaciens tfpA pilin gene $\mathrm{pMxN} 11$ as probe at a sodium salt concentration of $0.1 \mathrm{M}$ and a temperature of $65^{\circ} \mathrm{C}$. Genomic DNA of all strains was cut with Sau3AI. Lanes: 1, $\lambda /$ HindIII marker DNA visualized with a small amount of labelled $\lambda$ DNA; 2, NCTC 7784 (parent strain); 3, ATCC 19975 (type strain); 4, B2000/88; 5, B2000/88; 6, 3179/66; 7, 3179/66; 8, 178/62; 9, 13385/62; 10, ATCC $19968(836 / 61) ; 11,4378 / 62 ; 12,3067 / 66 ; 13,3832 / 60$.

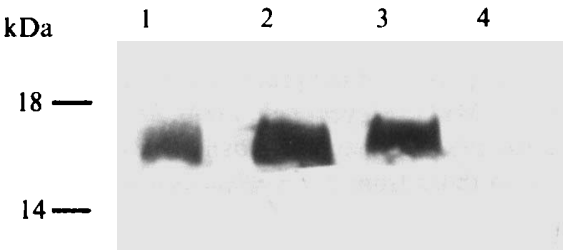

Fig. 5. Immunoblot analysis of crude pili and whole-cell extracts from $M$. nonliquefaciens NCTC 7784 and whole-cell extracts from $E$. coli containing cloned $M$. nonliquefaciens DNA. Lanes: 1, crude preparation of purified pili from $M$. nonliquefaciens NCTC $7784 ; 2, M$. nonliquefaciens NCTC 7784; 3, E. coli PLK- $\mathrm{F}^{\prime}$ with the plasmid pMxN11 (pGEM7 containing the $t p A$ pilin gene); 4, PLK-F' (pGEM7 without insert). Rabbit antiserum 130D raised against purified pili of $M$. nonliquefaciens NCTC 7784 was used at a dilution of 1:1000. Molecular mass markers are noted on the left.

$\mathrm{pMxB} 12$ contains parts of the region upstream of the gene in addition to the entire pilin gene $t f p Q$ (Marrs et al., 1985), while the $M$. nonliquefaciens clone pMxN11 contains little sequence outside of the pilin gene region tfpA (Fig. 1). The incomplete reciprocity of the hybridization results, i.e. the relatively strong heterologous signal given by $\mathrm{pMxB12}$, is considered to be due to sequence similarity between $\mathrm{pMxB} 12$ and $M$. nonliquefaciens DNA flanking the pilin gene. Greater sequence 


M. nonliquefaciens
N. gonorrhoeae
M. bovis
M. lacunata
D. nodosus
P. aeruginosa

M. nonliquefaciens

N. gonorrhoecue

M. horis

M. lacunata

D. nodosus

$P$. aeruginosa
MN A Q K G T I I L I I I I I I I G I I A A I A I D A I O D Y I A

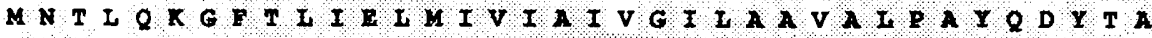

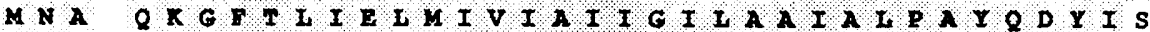

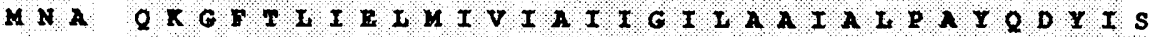
M K S L Q K G F T I I I I U I V V A I I G I I A A F A I P A I N D I I A

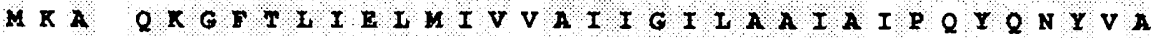

M. nonliquefaciens

N. gonorrhoeae

$M$. bovis

M. Lacunata

D. nodosus

P. aeruginosa

\begin{abstract}
R A Q V S E A F T
I I D G I T S I S N R O N RAQVS I A I I K S Q T T R V V G E IA A G K T A V D A A R S Q A A E G L T I A D G L K V R I S D H R S E A S A A S V N P L T T VEEA
\end{abstract}

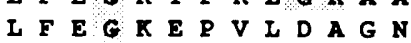

L E S E E K G D A N A L S R G S V K S G T G T

$M$. nonliquefaciens
N. gonorrhoeae
$M$. bovis
$M$. lacunata
D. nodosus
$P$. aeruginosa

M. nonliquefaciens

N. gonorrhoeae

$M$. bovis

M. lacunata

D. nodosus

$P$. aeruginosa

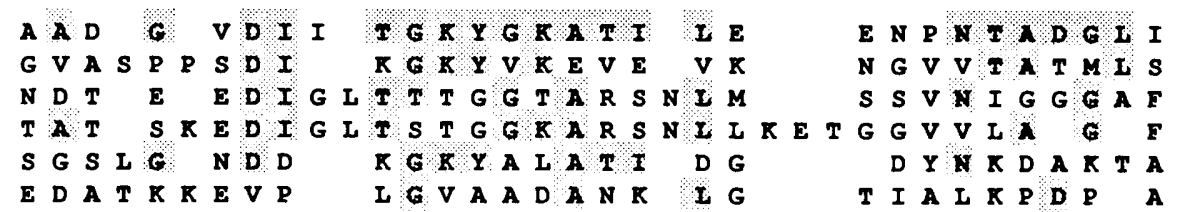

C 6 I Y Y D F N $S \in V N N I I K G$

A $T$ G A G I

S A T S S A G T I

1 \% V 8 D

K $\mathrm{L} \mathrm{s}$

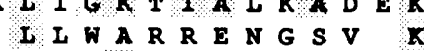

E A T L G N R A NKR D IA

GA V I T Q S R D A E G

I G T L G N R A N R D I

G A I I T $Q K$ K R A N D G

DEKNGCKVVIYYG Q G T A GEKISKIIVGK KIVID

D C T A D I T I T F T M G G A G P K N R G K I I T I T R T A A D G I

Fig. 6. Comparison of the predicted amino acid sequence of pilin from $M$. nonliquefaciens NCTC 7784 to the pilin sequences from $N$. gonorrhoeae MS11 (Meyer et al., 1984), M. bovis EPP63 tfpQ (Marrs et al., 1985), M. lacunata ATCC 17956 tfpQ (Rozsa \& Marrs, 1991), D. nodosus 198 (Ellemann \& Hoyne, 1984; McKern et al., 1983), and P. aeruginosa PAK (Sastry et al., 1985). Shaded residues are identical to those from $M$. nonliquefaciens pilin.

differences within the pilin genes than in the surrounding region have been observed between $M$. bovis and $M$. lacunata, where the $t f p Q$ genes are only $71 \%$ similar to each other as compared to $87 \%$ similarity over the entire pilin gene inversion region. This larger region includes the region $5^{\prime}$ of the pilin structural genes as well as the tfp $B$ and piv genes (Rozsa \& Marrs, 1991). Comparison of the nucleotide sequence of the $M$. nonliquefaciens t $f p A$ pilin gene (Fig. 3) to that of the $\operatorname{tfp} Q$ genes of $M$. bovis (Marrs et al., 1985) and M. lacunata (Rozsa \& Marrs, 1991 ), shows only $54 \%$ similarity in the DNA sequence.

As demonstrated in Fig. 2, the 10 strains of $M$. nonliquefaciens examined by hybridization analysis with the $t p A$ probe revealed several hybridizing bands. This suggested the existence of more than one pilin gene. Oligonucleotide hybridizations using probes specific for the $5^{\prime}$ and $3^{\prime}$ fragments flanking a potential inversion site reveals more bands with the $3^{\prime}$ and $t f p A$ probes than the $5^{\prime}$ probe, suggesting the existence of partial pilin genes lacking parts of the $5^{\prime}$ end of the gene (data not shown).

As we have shown, $t f p A$ is present in all the $M$. nonliquefaciens strains examined so far (Fig. 4). Since this pilin gene is detectably different in hybridization analysis from that of $M$. lacunata, this may be a means by which to distinguish clinical isolates of $M$. nonliquefaciens from those of $M$. lacunata.

Western blot analysis showed that the $M$. nonliquefaciens pilin gene is expressed in E. coli as a $15 \mathrm{kDa}$ protein, as compared to the $M$. nonliquefaciens purified pilin protein (Fig. 5). The pilin protein from the E. coli host strain migrates slightly more slowly than the pilin protein of the parent strain, as expected due to the leader sequence not being clipped off in the maturation process.

Comparison of the amino-terminal amino acid sequence of the mature $M$. nonliquefaciens pilin to the pilin amino acid sequence deduced from the DNA sequence 
of the $826 \mathrm{bp}$ insert present in pMxN11 shows that $t f p A$ encodes a protein with a six amino acid leader and 148 amino acids of the mature protein. Fig. 6 shows a comparison of the translated $M$. nonliquefaciens pilin sequence with the amino acid sequences of pilins from $N$. gonorrhoeae, $M$. bovis, $M$. lacunata, $D$. nodosus and $P$. aeruginosa. As aligned in Fig. 6, M. nonliquefaciens pilin matches with the others as follows: $41.6 \%$ identity with $N$. gonorrhoeae with 11 gaps, $39.6 \%$ identity with $M$. bovis with 12 gaps, $38.3 \%$ identity with $M$. lacunata with 15 gaps, $44.2 \%$ identity with $D$. nodosus with 12 gaps, and $31.8 \%$ identity with $P$. aeruginosa with 10 gaps. The relatively large amount of gapping reflects the fact that the alignment was not done in a simple pairwise maximization of sequence similarity, but has been adjusted to include alignment at positions conserved across all six pilins being compared. It is also worth noting that comparisons have previously been carried out on different pilin sequences present within the same $N$. gonorrhoeae strain which required as many as 6 gaps for optimal alignment (Nicholson et al., 1987).

It is notable that while $M$. nonliquefaciens is phylogenetically much closer to $M$. bovis and $M$. lacunata than to $N$. gonorrhoeae or $D$. nodosus, the amino acid sequence of the pilin protein of $M$. nonliquefaciens is about as similar to $N$. gonorrhoeae and $D$. nodosus pilins as it is to either $M$. bovis or M. lacunata pilin. This is in great contrast to the much higher similarity found between $M$. bovis and $M$. lacunata pilins (Rozsa \& Marrs, 1991). The $M$. nonliquefaciens pilin is identical in amino acid sequence to the pilins of $M$. bovis and $M$. lacunata starting with the six amino leader sequence and through the first 28 amino-terminal amino acids of the mature proteins. These regions are the most conserved among all of the type 4 pilins, but as can be seen in Fig. 6, pairwise comparisons of the other three pilins shown all differ from the Moraxella pilins in this region by at least five residues. However, amino acids $29-36$ of the mature pilins are identical between $M$. nonliquefaciens and $N$. gonorrhoeae, while only one residue in this region matches the amino acids found in the other Moraxella pilins. In $N$. gonorrhoeae pilins, amino acids 29-36 are part of the completely conserved region that does not vary during antigenic variation of pilin types. In a third major feature, the two cysteine residues in $M$. nonliquefaciens pilin have the central location observed in class I D. nodosus pilins, occurring at amino acids 56 and 97 of the mature pilin. In contrast, all type 4 pilins sequenced to date from $N$. gonorrhoeae, $P$. aeruginosa, $M$. bovis, and $M$. lacunata have a cysteine loop region very near the carboxy terminus of the pilin molecule. Class II $D$. nodosus pilins (Ellemann, 1988; McKern et al., 1983) and one $P$. aeruginosa strain (Pasloske et al., 1985) have cysteine pairs both centrally located and in the carboxy- terminal regions. In the $M$. nonliquefaciens pilin the positioning of the cysteines is similar to that seen in the class I $D$. nodosus pilin, coming at amino acids 56 and 93 of the mature pilin.

The significance of differential homologies between the $M$. nonliquefaciens pilin and the others discussed above is not yet clear. They might be of importance for colonization, adherence, and invasion of microhabitats by these species, as well as for escape from the host's immune defence. Further investigation of the pilin gene region will provide a basis for the study of adherence properties as well as other properties associated with piliation.

The work was supported by the Norwegian Research Council for Science and the Humanities, by 'Anders Jahres medisinske fond til vitenskapens fremme', and by the USA Public Health Service grant IR01EY07125 from the National Eye Institute.

\section{References}

Bergstrøm, S., Robbins, K., Koomey, J. M. \& Swanson, J. (1986) Piliation control mechanisms in Neisseria gonorrhoeae. Proceedings of the National Academy of Sciences of the United States of America 83 3890-3894.

BIRnboim, H. C. \& DOLY, J. (1979). A rapid alkaline extraction procedure for screening recombinant plasmid DNA. Nucleic Acids Research 7, 1513-1523.

Brorson, J. E., Falsen, E., Ehle-Nilsson, H., Rodjer, S. \& Westin, J. (1983). Septicemia due to Moraxella nonliquefaciens in a patient with multiple myeloma. Scandinavian Journal of Infectious Diseases 15, 221-223.

Bøvre, K. (1984), Genus II. Moraxella Lwoff 1939, 173 emend. Henriksen and Bøvre 1968, 391 AL. In Bergey's Manual of Systematic Bacteriology, vol. 1, pp. 296-303. Edited by N. R. Krieg \& J. G. Holt. Baltimore: Williams \& Wilkins.

BøVRE, K. \& FRøHOLM, L. O. (1972a). Variation of colony morphology reflecting fimbriation in Moraxella bovis and two reference strains of $M$. nonliquefaciens. Acta Pathologica et Microbiologica Scandinavica B80, 629-640.

Bøvre, K. \& Frøholm, L. O. (1972b). Competence in genetic transformation related to colony type and fimbriation in three species of Moraxella. Acta Pathologica et Microbiologica Scandinavica B80, 649-659.

Bøvre, K., Bergan, T. \& Frøholm, L. O. (1970). Electron microscopical and serological characteristics associated with colony type in Moraxella nonliquefaciens. Acta Pathologica et Microbiologica Scandinavica B78, 765-779.

DalRYMPle, B. \& MatTiCK, J. S. (1987). An analysis of the organization and evolution of type 4 fimbrial (MePhe) subunit proteins. Journal of Molecular Evolution 25, 261-269.

Dewhirst, F. E. Paster, B. J., La Fontaine, S. \& Rood, J. I. (1990). Transfer of Kingella indologenes (Snell and La Page, 1976) to the genus Suttonella gen. nov. as Suttonella indologenes comb. nov.; transfer of Bacteroides nodosus (Beveridge, 1941) to the Dichelobacter gen. nov., as Dichelobacter nodosus comb. nov.; and assignment of the genera Cardiobacterium, Dichelobacter and Suttonella to Cardiobacteriaceae fam. nov. in the gamma division of Proteobacteria based on $16 \mathrm{~S}$ ribosomal ribonucleic acid sequence comparisons. International Journal of Systematic Bacteriology 40, 426-433.

EBRIGHT, J. R., LenTINo, J. R. \& JUNI, E. (1982). Endophthalmitis caused by Moraxella nonliquefaciens. American Journal of Clincal Pathology 77, 362-363. 
EllemanN, T. C. (1988). Pilins of Bacteroides nodosus: molecular basis of serotypic variation and relationships to other bacterial pilins. Microbiological Reviews 52, 233-247.

Elleman, T. C. \& Hoyne, P. A. (1984). Nucleotide sequence of the gene encoding pilin of Bacteroides nodosus, the causal organism of ovine footrot. Journal of Bacteriology 160, 1184-1187.

Frøholm, L. O. \& Sletten, K. (1977). Purification and N-terminal sequencing of a fimbrial protein from Moraxella nonliquefaciens. FEBS Letters 73, 29-32.

Fulks, K. A., STePhens, S. P., Green, M. R. \& Marrs, C. F. (1990). Sequence analysis of the inversion region containing the pilin genes of Moraxella bovis. Journal of Bacteriology 172, 310-316.

Gold, L., Pribnow, D., Schneider, T., Shinedling, S., SwebiliusSINGER, B. \& STORMO, G. (1981). Translational initiation in prokaryotes. Annual Review of Microbiology 35, 365-403.

Graham, D. R., Band, J. D., Thornsberry, C., Hollis, D. G. \& WEAVER, R. E. (1990). Infections caused by Moraxella, Moraxella urethralis, Moraxella-like groups M-5 and M-6, and Kingella kingae in the United States, 1953-1980. Reviews of Infectious Diseases 12, 423431 .

Henrichsen, J., Frøholm, L. O. \& Bøvre, K. (1972). Studies on bacterial surface translocation. 2. Correlation of twitching motility and fimbriation in colony variants of Moraxella nonliquefaciens, $\boldsymbol{M}$. bovis, and M. kingii. Acta Pathologica et Microbiologica Scandinavica B80, 445-452.

Hermodson, M. A., Chen, K. C. S. \& Buchanan, T. M. (1978). Neisseria pilin proteins; amino-terminal amino-acid sequences and identification of an unusual amino acid. Biochemistry 17, 442-445.

Hull, R., Gill, R. E., Hsu, P., Minshew, B. H. \& FalKow, S. (1981) Construction and expression of recombinant plasmids encoding type 1 or D-mannose-resistant pili from a urinary tract infection Escherichia coli isolate. Infection and Immunity 33, 933-938.

Lobue, T. D., Deutsch, T. A. \& Stein, R. M. (1985). Moraxella nonliquefaciens endophthalmitis after trabeculectomy. American Journal of Ophthalmology 99, 343-345.

Marrs, C. F., SchoOlnik, G., KoOmey, J. M., Hardy, J., Rothbard, J. \& FALKOW, S. (1985). Cloning and sequencing of a Moraxella bovis pilin gene. Journal of Bacteriology 163, 132-139.

MarRs, C. F., Ruehl, W. W., SchoolnIK, G. K. \& Falkow, S. (1988). Pilin gene phase variation of Moraxella bovis is caused by an inversion of the pilin genes. Journal of Bacteriology 170, 30323039.

Marrs, C. F., Rozsa, F. W., Hackel, M., Stephens, S. P. \& GLASGOW, A. C. (1990). Identification, cloning, and sequencing of piv, a new gene involved in inverting the pilin genes of Moraxella lacunata. Journal of Bacteriology 172, 4370-4377.

MATTICK, J. S. (1989). The molecular biology of the fimbriae of Bacteroides nodosus and the development of a recombinant DNAbased vaccine against footrot. In Footrot and Foot Abscess of Ruminants, pp. 195-218. Edited by J. R. Egerton, W. K. Yang \& G. G. Riflkin. Boca Raton, Florida: CRC Press.

McKern, N. M., O'Donnel, I. J., Inglis, A. S., Stewart, D. J. \& ClarK, B. L. (1983). Amino acid sequence of pilin from Bacteroides nodosus (strain 198), the causative organism of ovine footrot. FEBS Letters 164, 149-153.

Meyer, T. F., Billyard, E., HaAs, R., Storzbach, S. \& So, M. (1984). Pilus genes of Neisseria gonorrhoeae: chromosomal organization and DNA sequence. Proceedings of the National Academy of Sciences of the United States of America 81, 6110-6114.
Nicolson, I. J., Perry, A. C. F., Virji, M., Heckels, J. E. \& SAUNDERS, J. R. (1987). Localization of antibody-binding sites by sequence analysis of cloned pilin genes from Neisseria gonorrhoeae. Journal of General Microbiology 133, 825-833.

Pasloske, B. L., Finlay, B. B. \& Paranchych, W. (1985). Cloning and sequencing of the Pseudomonas aeruginosa PAK pilin gene. FEBS Letters 183, 408-412.

RosetT, W., Heck, D. M. \& Hodges, G. R. (1976). Pneumonitis and pulmonary abscess associated with Moraxella nonliquefaciens. Chest 70, 664-665.

Rozsa, F. W. \& MARRS, C. F. (1991). Interesting sequence differences between the pilin gene inversion regions of Moraxella lacunata ATCC 17956 and Moraxella bovis EPP63. Journal of Bacteriology 173 (in the Press).

Sambrook, J., Fritsch, E. F. \& Maniatis, T. (1989). Molecular Cloning : a Laboratory Manual, 2nd edn, pp. 1.90-1 . 104. Cold Spring Harbor, NY: Cold Spring Harbor Laboratory.

SANGER, F., Nicklen, S. \& Coulson, A. R. (1977). DNA sequencing with chain terminating inhibitors. Proceedings of the National Academy of Sciences of the United States of America 74, 5463-5467.

Sastry, P. A., Finlay, B. B., Pasloske, B. L., Paranchych, W., Pearlstone, J. R. \& Smillie, L. B. (1985). Comparative studies of the amino acid and nucleotide sequences of pilin derived from Pseudomonas aeruginosa PAK and PAO. Journal of Bacteriology 164, 571-577.

SChoolnik, G. K., TAI, J. Y. \& Gotschlich, E. C. (1982). The human erythrocyte binding domain of gonococcal pili. Seminars of Infectious Diseases 4, 172-180.

Sharma, D. L. B. (1974). Fatal septicaemia due to Moraxella nonliquefaciens. Archives of Diseases in Children 49, 966-967.

SOUTHERN, E. M. (1975). Detection of specific sequences among DNA fragments separated by gel electrophoresis. Journal of Molecular Biology 98, 503-517.

Stoker, N. G., Fairweather, N. C. \& Spratt, B. G. (1982). Versatile low-copy number vectors for cloning in Escherichia coli. Gene 18, 335-341.

SWANSON, J. \& KoOmey, J. M. (1989). Mechanisms for variation of pili and outer membrane protein II in Neisseria gonorrhoeae. In Mobile $D N A$, pp. 743-761. Edited by D. Berg \& M. Howe. Washington, DC. American Society for Microbiology.

Swanson, J., Robbins, K., Barrera, O., Corwin, D., Boslego, J., ClaK, J., Blake, M. \& KoOMEY, J. M. (1987). Gonococcal pilin variants in experimental gonorrhoeae. Journal of Experimental Medicine 165, 1344-1357.

Taylor, R. K., Miller, V. L., Furlong, D. B. \& Mekalanos, J. J (1987). Use of phoA gene fusions to identify a pilus colonization factor coordinately regulated with cholera toxin. Proceedings of the National Academy of Sciences of the United States of America 81, 2833-2837.

Towbin, H., Staehelin, T. \& Gordon, J. (1979). Electrophoretic transfer of proteins from polyacrylamide gels to nitrocellulose sheets: procedure and some applications. Proceedings of the National Academy of Sciences of the United States of America 76, 4350-4354.

TøNJum, T., Bukholm, G. \& Bøvre, K. (1989). Differentiation of some species of Neisseriaceae and other bacterial groups by DNA-DNA hybridization. APMIS 97, 395-405.

WEST, S. E. H. \& CLARK, V. L. (1989). Genetic loci and linkage associations in Neisseria gonorrhoeae and Neisseria meningitidis. Clinical Microbiological Reviews 2, S92-S103. 